\title{
ON THE RELATIONSHIP BETWEEN HUMAN CAPITAL INEQUALITY AND GLOBALIZATION
}

\author{
Yasmin Bani* \\ Universiti Putra Malaysia
}

\begin{abstract}
This study attempts to tackle the inequality and globalization issue by departing from the usual convention and studying the effect of globalization on another distribution, which is the distribution of human capital. We would like to investigate whether globalization helps to alleviate or worsen inequality in education and benefit everyone in the observed population in the same way in terms of education. Moreover, we would also like to analyze whether the benefit or loss experienced by countries differ across the level of development. Our focus is on the impact of the composite index of globalization as well as its three different dimensions on education inequality. The study shows that the developing countries (low and middle-income countries) do not necessarily benefit from globalization, which clearly contradicts the standard trade theory. This is because we observe the existence of variation of effects within the developing countries itself. Globalization narrows the education gap in low-income countries but it widens the gap in middle-income countries. Additionally, the study also show the importance of social and political globalization, which is often ignored in existing literature. The results are robust to different measures of globalization, exclusion of countries from different regions and inclusion of several control variables.
\end{abstract}

Keywords: Globalization; Human Capital Inequality; System GMM.

\section{INTRODUCTION}

The debate on the effect of globalization on income distribution is often divided between two points of view. Under the Stolper-Samuelson theorem of the Heckscher-Ohlin (H-O) theory, globalization should be beneficial for poor and developing countries by reducing inequality and giving opportunities for least educated workers to acquire the benefits of globalization (Kremer and Maskin, 2003). Various studies (Tayebi and Ohadi (2009), Bechtel (2014) among others) have found that globalization leads to the rise of income, which will benefit not only the high-income, but also low-income groups. On the contrary, some studies argue that the opportunities and benefits of globalization are not shared equally among the citizens, thus widening the gap between the low and high-income groups (see Kanbur (2000), Basu and Guariglia (2007), Gaston and Rajaguru (2009), Bergh and Nilsson (2010) among others). Cross-country studies on developing countries based on H-O theory generally imply that trade liberalization is associated with higher inequality and does not benefit poor income countries as pointed out by Kremer and Maskin (2003). Others have also found insignificant effect of globalization on inequality, which contradicts the theory ${ }^{1}$. Calderon and Chong (2001) prove that greater openness leads to lower inequality in developing countries. It is still a debate in both theoretical and empirical literature of

\footnotetext{
* Corresponding author: Department of Economics, Faculty of Economics and Management, Universiti Putra Malaysia, 43400 Serdang, Selangor, Malaysia. Email: nor_yasmin@upm.edu.my

${ }^{1}$ There are additional factors that may contribute to the contrasting evidence in existing literature. First, different studies use different sample countries and cover different sample periods. Second, different proxies measure the term 'globalization'. Some use openness and FDI while others use policies measures such as tariffs or quotas. Finally, researchers use different econometrics specifications in their studies. The usual approach has been the levels on levels regression in a cross-section analysis, while recently studies have focus to the panel relationship.
} 
whether globalization is associated with narrowing or widening income distribution within the developing countries.

This study aims to contribute to the existing literature by attempting to prove and analyze the competence of the standard $\mathrm{H}-\mathrm{O}$ theory on inequality and globalization. We tackle the inequality and globalization issue by departing from the usual convention and studying the effect of globalization on another distribution, which is the distribution of human capital ${ }^{2}$. In other words, we would like to investigate whether globalization helps to alleviate or aggravate inequality in education and benefit everyone in the observed population in the same way in terms of education. Moreover, we would also like to analyze whether the benefit or loss experienced by countries differ across the level of development.

The main objectives of this chapter are to answer the following questions:

(1) How is globalization related to human capital inequality?

(2) Does the effect of globalization depend on the level of development of a country?

Deininger and Squire (1998) argue that income inequality maybe a poor proxy for distribution of wealth and propose land inequality as an alternative measure. It is non-trivial to study human capital inequality to proxy for wealth/asset inequality for a number of reasons. First, the stock of human capital is one of the determinants of current and future income; hence, the distribution of human capital can provide a good indicator of income inequality. Glomm and Ravikumar (1992), Saint-Paul and Verdier (1993) and Galor and Tsiddon (1997) among others develop models that show the main source of inequality is the distribution of human capital. Second, the human capital distribution can be considered as approximate determinants of the distribution of earnings since it is determined by individual ability and investment financing (Thomas et al., 2001). Lastly, an equal distribution of human capital is an important factor in determining individual productivity and reducing poverty besides land or other wealth indicators. Human capital can be considered as an opportunity and the equal distribution of opportunity is always preferred than the distribution of wealth because of its spillover effects (Thomas et al., 2001).

Additionally, Checchi (2001) asserts that income inequality and educational choice are two different concepts, which are often misled by the theoretical assumptions. In many theoretical models ${ }^{3}$, income inequality and educational choice are assumed to be perfectly correlated and influenced by the same factors. In those models, factors like poverty, imperfect credit market and inefficient tax levying administration prevent access to education and lead to population with low earnings. Therefore, the poor and the uneducated are usually the same person, although in reality the relationship is far more complicated. Educational choice is closely related to public provision of schools while income distribution is more related to employment composition and fiscal policies. Nonetheless, income inequality and education inequality are obviously related; the more skewed the income distribution, the higher the inequality in education (Checchi, 2001). Thus, by studying education inequality, we may be able to find the transmission mechanism in explaining the relationship between income distribution and other variables.

\footnotetext{
${ }^{2}$ The term 'human capital' in this chapter refers only to education. However, the term 'human capital' and 'education' is used interchangeably throughout the chapter.

${ }^{3}$ These are the models explained in Galor and Ziera (1993), Banerjee and Newman (1993) and Piketty (1997) among others.
} 
Our focus is on the impact of the composite index of globalization as well as its three different dimensions on education inequality. The analysis utilizes a new dataset on globalization indices recently developed by Dreher (2006) known as the KOF Index of globalization. So far, only Dreher and Gaston (2008) and Bergh and Nilsson (2010) have analyzed the relationship between the KOF index and income inequality. In addition, we also examine the impact of three additional measures of globalization that are used commonly in previous studies for comparison and robustness tests.

To anticipate our result, we find that the effect of globalization on human capital inequality differs according to the level of income. The novel finding of this study is that globalization matters for human capital inequality and although globalization conceptually should be beneficial for developing countries, the hypothesis only holds for low-income countries. On the other hand, globalization worsens the inequality in education in middle and high-income countries. The novelty of our results clearly shows that there is a variation of effect within the developing countries itself which challenge the H-O theory. Different dimensions of globalization have similar effects on inequality, which proves that not only economic globalization, but also social and political globalization are important in the relationship. This is also true when we measure globalization by FDI inflow and EF index. Inversely, when measured by trade openness, we do not find any significant evidence.

Existing studies that focus on the direct effects of globalization on human capital inequality are limited. Basu and Guariglia (2007) have presented stylized facts related to the interactions between foreign direct investments (FDI), educational inequality (for the population 15 years and above), growth and the share of agriculture to GDP in 119 developing countries. To explain these stylized facts, they develop a growth model showing that FDI, inequality and growth are positively related. They conclude "FDI induced growth exacerbates human capital inequality" (Basu and Guariglia, 2007). This study, however, does not include the high-income countries and does not take into account the different effects that FDI may have on different levels of incomes. Our study analyzes the effect of globalization on educational inequality and our results show that developing countries do not necessarily benefit from globalization, which clearly contradicts the standard trade theory.

\section{LITERATURE REVIEW}

Abundant research studies have been conducted in recent years on the relationship between globalization and aggregate inequality, but with conflicting evidence either from theoretical or empirical perspective. Since there is limited literature on the relationship between human capital inequality and globalization, our review will be based on other inequality measures and globalization. Kanbur (2000) studies the relationship between trade openness and income inequality from a theoretical perspective. He describes a simple intuition of the $\mathrm{H}-\mathrm{O}$ theory in a model including both skilled and unskilled workers, where skilled workers are primarily from rich countries. He predicts that trade openness will increase inequality in rich countries but reduce within country inequality in less developed countries. This is in contrast with the earlier finding by Savvides (1998), who claims that a less developed country that is more open to trade will experience increases in income inequality.

Empirical studies have tested various hypotheses about the effects of globalization on inequality within developing countries (see for example, Ravallion, 2001, Calderon and Chong, 2001; Lundberg and Squire, 2003, among others). The usual models test the hypothesis of whether the globalizationelasticity of inequality depends on the level of development by introducing an interaction term between 
openness and GDP per capita or a dummy for OECD countries ${ }^{4}$. The theoretical foundation of this empirical model is based on the basic $\mathrm{H}-\mathrm{O}$ trade theory and the support of this theory requires a negative value for the level of development and a positive value for the globalization measure.

In an attempt to prove the theory, Milanovic (2005) examine the effects of trade openness and foreign direct investment on relative income shares of the lowest and highest quintile. His result shows that globalization hurts the poor, by widening the gap of income distribution. As income levels rise, the benefits flow to the poor and middle class more than the rich ones. However, he does not find any significant effect of foreign direct investment on any quintile.

Sylwester (2005), for example, studies the relationship for 29 Less Developed Countries (LDCs) and concludes that FDI does not have any significant effect on income inequality for these sample countries. Lundberg and Squire (2003) and Dollar and Kraay (2002) obtain similar results. The former finds weak evidence that globalization increases poverty and inequality in the short run. The latter, finds insignificant effect of openness and the income share of bottom quintiles.

In short, cross-country studies have yield contrasting and controversial results on the relationship between globalization and inequality. Some studies find an insignificant effect of globalization; others find that globalization has reduced the gap between the rich and the poor. Existing studies focus only on economic globalization, ignoring both social and political integration. Furthermore, income inequality measures are scarce and incomparable between countries, a reason in which the findings are conflicting with each other. Human capital Gini may provide a better result, as it is available for a wide range of countries and it complements the information provided by income inequality (Castelló and Doménech, 2002). Human capital Gini is largely ignored in analyzing the relationship. Apart from Basu and Guariglia (2007), no other study has focused on the effects of globalization on the distribution of human capital; hence, the study fills in the gap.

\section{DATA DESCRIPTION}

To test the hypothesis, we evaluate the effects of globalization according to the level of development of a country inspired by the H-O trade theory. According to the theoretical framework, we expect that globalization narrows the education inequality gap in developing countries (low and middle-income countries) and widens it in high-income, which consists of developed countries. The sample consists of an unbalanced panel of observations from 112 developing and developed countries around the world covering the period 1970-2009 for which the education inequality and the composite KOF index are available together.

The variables are averaged over non-overlapping five year period to reduce the possibility of business cycles and measurement errors, thus resulting in eight distinct periods. However, as we include several control variables, the effective sample of the study is smaller than the possible observations due to missing data. The final sample reduces to 108 countries (27 low income, 49 middle income and 32 highincome countries) with a maximum of 688 observations. The number of countries and observations change depending on the variables considered in the specifications. The countries are categorized based on the World Bank specifications; however, we categorized the countries into two broad specifications,

\footnotetext{
${ }^{4}$ Andersen (2005) provides details on these studies.
} 
namely the developing countries (low income and middle income countries, including upper middle income countries) and developed countries.

\subsection{Human Capital Gini}

Gini coefficients are the most commonly used measure of inequality. Income inequality is used to proxy for wealth inequality because of the absence of data on the distributions of wealth for countries. Some studies use Gini coefficients of land distribution (Alesina and Rodrik, 1994) or land inequality together with income inequality to analyze the relationship between the distribution of assets and growth (Deininger and Squire, 1998). The stock of human capital (measured by the average years of schooling) is another important component of wealth and asset that has been neglected in measuring inequality (Castelló and Doménech, 2002). Thomas et al. (2001) argue that an equal distribution of education is a vital necessity to lift people out of poverty and enhance individual productivity. Furthermore, Burtless (2002) has argued that income may not be the suitable proxy to examine the effect of globalization on inequality. Thus, we deviate from the usual convention by using the Gini coefficients of education as a proxy for wealth inequality to gain a better understanding of the link between globalization and inequality.

Similar to other measures of distributions (income, wealth or land), human capital Gini ranges from 0 (perfect equality) to 1 (perfect inequality). To measure human capital inequality, we follow the calculations from Castelló and Doménech (2002). We utilize recent and updated educational attainment data from Barro and Lee (2010). The human capital Gini is calculated as follows:

$$
\text { GiniEd }=\frac{1}{2 \bar{H}} \sum_{i=0}^{3} \sum_{j=0}^{3}\left|\hat{x}_{i}-\hat{x}_{j}\right| n_{i} n_{j}
$$

where $\bar{H}$ is the average years of schooling for the population aged 15 years or 25 years and above and $i$ and $j$ are indices of the levels of education. $n_{i}$ and $n_{j}$ are the share of population with a given level of education. $\hat{x}_{i}$ and $\hat{x}_{j}$ are the cumulative average years of schooling for each level and we consider four levels of education based on Barro and Lee (2010) classification: no schooling $(x=0)$, primary education $(x=1)$, secondary education $(x=2)$ and tertiary education $(x=3)$. The cumulative average years of schooling for each level are:

$$
\begin{aligned}
& \hat{x}_{0}=x_{0}=0 \\
& \hat{x}_{1}=x_{1} \\
& \hat{x}_{2}=x_{1}+x_{2} \\
& \hat{x}_{3}=x_{1}+x_{2}+x_{3}
\end{aligned}
$$

The average number of years of schooling, $\bar{H}$, is calculated as follows:

$$
\bar{H}=n_{1} x_{1}+n_{2}\left(x_{1}+x_{2}\right)+n_{3}\left(x_{1}+x_{2}+x_{3}\right)
$$

Expanding (4.1) and taking (4.2) and (4.3), the education Gini is computed based on this formula ${ }^{5,6}$ :

\footnotetext{
${ }^{5}$ For more details of the calculations, refer to Castelló and Doménech (2002). For similar calculations, refer to Checchi (2001). ${ }^{6}$ Where $n_{0}=l u 25 ; n_{l}=l p 25 ; n_{2}=l s 25 ; n_{3}=l h 25, \bar{H}=y r_{-} s c h 25, \mathrm{x}_{0}=0, \mathrm{x}_{1}=\mathrm{yr} \_s c h \_p r i 25 /(\operatorname{lp} 25+1 \mathrm{~s} 25+\mathrm{lh} 25), \mathrm{x}_{2}=\mathrm{yr} \_s c h \_s e c 25 /(\mathrm{ls} 25+\mathrm{lh} 25)$ and $\mathrm{x}_{3}=\mathrm{yr} \_s c h \_h 25 / \mathrm{lh} 25$. In the Barro-Lee dataset, $l u 25$ is the percentage of "no schooling"; lp25 is the percentage of "primary school attained"; $l s 25$ is the percentage of "secondary school attained"; $l h 25$ is the percentage of "higher school attained"; $y r \_s c h 25$ is the average schooling
} 


$$
\text { GiniEd }=n_{0}+\frac{n_{1} x_{2}\left(n_{2}+n_{3}\right)+n_{3} x_{3}\left(n_{1}+n_{2}\right)}{n_{1} x_{1}+n_{2}\left(x_{1}+x_{2}\right)+n_{3}\left(x_{1}+x_{2}+x_{3}\right)}=n_{0}+\frac{n_{1} x_{2}\left(n_{2}+n_{3}\right)+n_{3} x_{3}\left(n_{1}+n_{2}\right)}{\bar{H}}
$$

\subsection{Independent Variables}

To measure globalization, we use the KOF index (Dreher, 2006; Dreher et al., 2008) which measures three different dimensions of globalization; economic (KOF1) (actual trade flows and restrictions); social (KOF2) (personal contact, information flows and cultural proximity) and political globalization (KOF3) (number of embassies and membership in international organizations). We also use the composite measure of the index $(\mathrm{KOF})$, which is the weighted average of the three-globalization dimensions. In either case, the value of the index is between 0 and 100; values closer to 100 indicate higher globalization.

As argued by Dreher (2006), globalization is a multidimensional concept which includes different dimensions and is not restricted to trade openness or capital movements. Thus, it is important to use an inclusive variable to measure the effect of globalization on other macroeconomics variables. Therefore, the KOF index may provide a more comprehensive view of the relationship compared to the traditional measure of globalization ${ }^{7}$. The details of the index and the dimensions are listed in the Appendix. We transform the index into logarithm to capture the non-linearity between human capital inequality and the globalization index.

To check the robustness of the results, we also use three additional proxies for globalization (which has been widely used in existing literature), which are openness to trade (Openness), foreign direct investment $(F D I)$ and freedom to trade internationally (EF index) Openness to trade is measured as the ratio of total trade to GDP and has been employed by previous studies on globalization. Foreign direct investment inflow (FDI) is taken from the World Bank-World Development Indicator (WDI). We also choose the fourth dimension of the Economic Freedom of the World Index, which is the freedom to trade internationally as another proxy for globalization. This index combines the measures of trade taxes, tariffs and barriers as well as capital market controls and is closely related to economic globalization index (KOF1). The index range from 0 to 10 and is developed by Gwartney and Lawson (2003).

We include additional control variables in the specification to examine the impact of other factors on education inequality. Because of the absence of a theory that explains the determinants of education inequality, we rely on existing study (Castelló and Doménech, 2002; Checchi and Garcia-Penalossa, 2004) in choosing the control variables. We add three control variables to the baseline regression model. First, we include the log of Real GDP per capita to control for the level of development. It is also a good predictor of a country's educational achievement (Checchi and Garcia-Penalosa, 2004). To capture the primary effect of demographic structure, we include the age dependency ratio for population younger than 15 years old and older than 64 years old. The likelihood of seeking education might depend on the size of the household (how many children a family has) and on the age structure of the household. We expect that higher dependency ratio is associated with higher human capital inequality. Lastly, we include private credit as a percentage of GDP (ratio of credit to the private sector by deposit money banks and other financial institutions) as a measure of financial development. The data is from Beck

years in the population; $y r \_s c h \_p r i 25$ is the average years of primary schooling in the population; $y r \_s c h \_s e c 25$ is the average years of secondary schooling in the population; $y r_{-} s c h \_h 25$ is the average years of higher schooling in the population.

${ }^{7}$ Previous literature has used openness to trade or foreign direct investments as proxy for globalization. Others have used Sachs and Warner (1995) openness index or Kearney/Foreign Policy globalization index. 
and Demirguc-Kunt (2009) and it is an important variable to proxy for the ability to borrow to finance educational costs.

\section{EMPIRICAL SPECIFICATION}

We adopt an empirical model similar to Bergh and Nilsson (2010) to study the effect of globalization on inequality and to answer our first question. A panel regression model is formulated as below:

$$
E_{i t}=\alpha+\text { Global }_{i t} \beta+X_{i t} \gamma+\delta_{i}+\rho_{t}+\varepsilon_{i t}
$$

The dependent variable, $E_{i t}$ is the Education Gini for population aged 25 years and above and Global $_{i t}$ is the vector of globalization indices and measures. We include several covariates in $X_{i t}{ }_{i t}$ stated explicitly in the previous section. $\delta_{\mathrm{i}}$ is the country fixed effect, $\rho_{\mathrm{t}}$ is the year fixed effect and $\varepsilon_{\mathrm{it}}$ is the error term. $i$ and $t$ represent countries and time respectively.

To examine whether the effect of globalization varies by level of income, we construct two variables: $\left(\right.$ Global $_{i t} *$ DummyMid $\left._{i t}\right)$ and $\left(\right.$ Global $_{i t}{ }^{*}$ DummyHit $\left._{i t}\right)$. The first variable is an interaction term between the globalization measure with a dummy variable, 1 for middle income countries and 0 for others $\left(\right.$ DummyMid $\left._{i t}\right)$. Similarly, the second variable is the interaction between globalization and dummy variable for high-income countries $\left(\right.$ DummyHi $\left._{i t}\right)$. All variables are expressed in 5-year averages.

$$
\begin{aligned}
E_{i t}= & \alpha+\beta_{1} \text { Global }_{i t}+\beta_{2} \text { DummyMid }_{i t}+\beta_{3} \text { DummyHi }_{i t}+\beta_{4}\left(\text { Global }_{i t} * \text { DummyMid }_{i t}\right) \\
& +\beta_{5}\left(\text { Global }_{i t} * \text { DummyH }_{t}\right)+\beta_{6} X_{i t}^{\prime}+\delta_{i}+\rho_{t}+\varepsilon_{i t}
\end{aligned}
$$

Estimating the above equation by least squares will raise the issue of potential endogeneity among the variables of interests. This may be due to the correlation of the explanatory variables. It is possible that the level of globalization is affected by the changes in human capital inequality or vice versa.

There is a powerful method to handle the endoegeneity problem, which is the system GMM estimator introduced by Arellano and Bover (1995) and further developed by Blundell and Bond (2000). The system GMM estimator uses additional moment condition compared to the first-difference estimator originally developed by Holtz-Eakin et al. (1998) and Arellano and Bond (1991). This method uses lagged differences as instruments in the level equation and lagged levels as instruments for the difference equation (Arellano and Bover, 1995, and Blundell and Bond, 2000). The estimator is consistent in the presence of endogenous variables and suitable instruments.

System GMM controls for the unobserved country specific effects by differentiating the model to eliminate the country specific effects or any time-invariant country specific variable and is suitable for panels with small $T$ and large $N$. The system GMM regressions are conducted by implementing Roodman (2009a, 2009b) two-step method and Windmeijer (2005) finite sample corrections. Dreher and Gaston (2008) and Bergh and Nilsson (2010) have used system GMM in their study. The system GMM estimator is consistent under the absence of second order serial autocorrelation and the presence of valid instruments. We compute two diagnostic tests for first order and second order serial correlation in the disturbances. We should reject the null of the absence of first order serial correlation and accept the null of the absence of second order serial correlation. For the validity of the instruments, we conduct the Hansen-J test of over-identifying restrictions, which we should not reject the null that the instruments are uncorrelated with the error term. 


\section{RESULTS AND DISCUSSION}

We begin the empirical analysis by estimating a baseline regression without the interaction terms. The dependent variable in all analysis is the education Gini for population aged 25 years and above. In all regressions, the globalization indices (and alternative measures) are treated as endogenous. Results are presented in Table 1 for the KOF indices ${ }^{8}$. All the indices are negative and significant as expected. Age dependency is only significant in KOF1 and KOF2 regressions. On the other hand, GDP does not show any effects on human capital inequality. Finance is positive and significant in all regressions which imply that good financial development will widen the education inequality gap. The regressions also passed the over identification test for instrument validity and first and second order serial correlation. The results indicate that, in general, more globalized countries have smaller education gap. Globalization narrows the education inequality gap in the sample countries considered. This is also true when we examine the index separately.

Table 1: Human Capital Inequality and Globalization: Baseline Regression [System GMM]

\begin{tabular}{|c|c|c|c|c|}
\hline "Variables & (1) System & (2) System & (3) System & (4) System \\
\hline KOF & $\begin{array}{l}-0.043 * * \\
(0.019)\end{array}$ & & & \\
\hline KOF1 & & $\begin{array}{l}-0.047 * * * \\
(0.017)\end{array}$ & & \\
\hline $\mathrm{KOF} 2$ & & & $\begin{array}{l}-0.020^{*} \\
(0.012)\end{array}$ & \\
\hline KOF3 & & & & $\begin{array}{l}-0.029 * \\
(0.017)\end{array}$ \\
\hline Gini25 $(t-1)$ & $\begin{array}{l}0.831 \text { *** } \\
(0.026)\end{array}$ & $\begin{array}{l}0.821 \text { *** } \\
(0.024)\end{array}$ & $\begin{array}{l}0.837 \text { *** } \\
(0.023)\end{array}$ & $\begin{array}{l}0.840^{* * * *} \\
(0.025)\end{array}$ \\
\hline GDP & $\begin{array}{l}-0.006 \\
(0.005)\end{array}$ & $\begin{array}{l}-0.004 \\
(0.004)\end{array}$ & $\begin{array}{l}-0.005 \\
(0.004)\end{array}$ & $\begin{array}{c}-0.010 * * \\
(0.004)\end{array}$ \\
\hline Finance & $\begin{array}{l}0.008 * * * \\
(0.003)\end{array}$ & $\begin{array}{l}0.009 * * * \\
(0.003)\end{array}$ & $\begin{array}{l}0.007 * * \\
(0.003)\end{array}$ & $\begin{array}{c}0.006^{*} \\
(0.003)\end{array}$ \\
\hline Age & $\begin{array}{c}0.022 \\
(0.015)\end{array}$ & $\begin{array}{l}0.027 * * \\
(0.012)\end{array}$ & $\begin{array}{l}0.027 * * \\
(0.012)\end{array}$ & $\begin{array}{c}0.018 \\
(0.017)\end{array}$ \\
\hline Constant & $\begin{array}{c}0.177 \\
(0.117)\end{array}$ & $\begin{array}{c}0.158 \\
(0.101)\end{array}$ & $\begin{array}{c}0.050 \\
(0.069)\end{array}$ & $\begin{array}{c}0.174 \\
(0.127)\end{array}$ \\
\hline Observations & 687 & 662 & 687 & 687 \\
\hline AR1 $p$-value & 0.02 & 0.02 & 0.02 & 0.02 \\
\hline AR2 $p$-value & 0.11 & 0.12 & 0.12 & 0.12 \\
\hline Hansen $\mathrm{J} p$-value & 0.30 & 0.12 & 0.16 & 0.06 \\
\hline
\end{tabular}

Notes: Robust standard errors in parentheses. ${ }^{* * *} \mathrm{p}<0.01,{ }^{* *} \mathrm{p}<0.05,{ }^{*} \mathrm{p}<0.1$. The dependent variable is human capital gini for population aged 25 years and above. Significant time dummies are included in every regression.

Table 2 presents the results of estimating the effect of globalization on different levels of income. The result does not change when we add the interaction term to differentiate countries. The composite KOF index is negatively related to human capital inequality. When testing the dimensions of the index separately (columns 2-4), it appears that all the dimensions show similar results. It is worth noting that while our results generally claim that globalization has decreased human capital inequality, it is still

\footnotetext{
${ }^{8}$ We also estimate the equation using three different methods: Pooled OLS, Random effects and Fixed Effects before employing system GMM. Results are available on request.
} 
difficult to argue which dimension of globalization is most responsible for the overall impact. This is because the effect of different dimensions varies across the sample and population age.

Table 2.a: Human Capital Inequality and Globalization: Different Levels of Development: System GMM

\begin{tabular}{|c|c|c|c|c|}
\hline Variables & (1) KOF & (2) KOF1 & (3) KOF2 & (4) KOF3 \\
\hline KOF & $\begin{array}{l}-0.054 * * * \\
(0.016)\end{array}$ & & & \\
\hline KOF*Middle & $\begin{array}{l}0.059 \text { *** } \\
(0.014)\end{array}$ & & & \\
\hline KOF*High & $\begin{array}{c}0.038^{*} \\
(0.020)\end{array}$ & & & \\
\hline $\mathrm{KOF} 1$ & & $\begin{array}{l}-0.056^{* * *} \\
(0.016)\end{array}$ & & \\
\hline KOF $1 *$ Middle & & $\begin{array}{l}0.048 * * * \\
(0.015)\end{array}$ & & \\
\hline KOF1*High & & $\begin{array}{l}0.044 * * \\
(0.020)\end{array}$ & & \\
\hline KOF2 & & & $\begin{array}{l}-0.028 * * \\
(0.014)\end{array}$ & \\
\hline KOF $2 *$ Middle & & & $\begin{array}{l}0.034 * * \\
(0.015)\end{array}$ & \\
\hline KOF2*High & & & $\begin{array}{c}0.018 \\
(0.016)\end{array}$ & \\
\hline KOF3 & & & & $\begin{array}{l}-0.046^{* * *} \\
(0.015)\end{array}$ \\
\hline KOF3*Middle & & & & $\begin{array}{l}0.053^{* * * *} \\
(0.014)\end{array}$ \\
\hline KOF3*High & & & & $\begin{array}{l}0.045^{* * *} \\
(0.019)\end{array}$ \\
\hline Gini25t-1 & $\begin{array}{l}0.864 * * * \\
(0.018)\end{array}$ & $\begin{array}{l}0.837 * * * \\
(0.020)\end{array}$ & $\begin{array}{l}0.864 * * * \\
(0.018)\end{array}$ & $\begin{array}{l}0.879 * * * \\
(0.018)\end{array}$ \\
\hline Middle & $\begin{array}{l}-0.221 \text { *** } \\
(0.051)\end{array}$ & $\begin{array}{l}0.172 * * * \\
(0.058)\end{array}$ & $\begin{array}{l}-0.114 * * \\
(0.046)\end{array}$ & $\begin{array}{l}-0.208^{* * * *} \\
(0.059)\end{array}$ \\
\hline High & $\begin{array}{l}-0.116 \\
(0.080)\end{array}$ & $\begin{array}{c}-0.138^{*} \\
(0.077)\end{array}$ & $\begin{array}{l}-0.024 \\
(0.058)\end{array}$ & $\begin{array}{c}-0.145^{*} \\
(0.080)\end{array}$ \\
\hline GDP & $\begin{array}{l}-0.009 \\
(0.006)\end{array}$ & $\begin{array}{l}-0.013 \\
(0.009)\end{array}$ & $\begin{array}{l}-0.014 \\
(0.010)\end{array}$ & $\begin{array}{l}-0.020 * * \\
(0.009)\end{array}$ \\
\hline Finance & $\begin{array}{l}0.006^{* *} \\
(0.002)\end{array}$ & $\begin{array}{l}0.007 * * \\
(0.003)\end{array}$ & $\begin{array}{c}0.005^{*} \\
(0.003)\end{array}$ & $\begin{array}{l}0.006^{* * *} \\
(0.002)\end{array}$ \\
\hline Age & $\begin{array}{l}0.032 * * * \\
(0.011)\end{array}$ & $\begin{array}{l}0.033 * * \\
(0.013)\end{array}$ & $\begin{array}{l}0.029 * * \\
(0.013)\end{array}$ & $\begin{array}{c}0.014 \\
(0.016)\end{array}$ \\
\hline Constant & $\begin{array}{c}0.181 * \\
(0.105)\end{array}$ & $\begin{array}{c}0.218^{*} \\
(0.128)\end{array}$ & $\begin{array}{c}0.119 \\
(0.132)\end{array}$ & $\begin{array}{l}0.317 * * \\
(0.139)\end{array}$ \\
\hline Observations & 687 & 662 & 687 & 687 \\
\hline Countries & 108 & 104 & 108 & 108 \\
\hline AR1 $p$-value & 0.02 & 0.02 & 0.02 & 0.01 \\
\hline AR2 $p$-value & 0.11 & 0.10 & 0.11 & 0.11 \\
\hline Hansen $\mathrm{J} p$-value & 0.35 & 0.38 & 0.27 & 0.31 \\
\hline
\end{tabular}

Notes: Robust standard errors in parentheses. ${ }^{* * *} \mathrm{p}<0.01,{ }^{* *} \mathrm{p}<0.05,{ }^{*} \mathrm{p}<0.1$. The dependent variable is human capital gini for population aged 25 years and above. Significant time dummies are included in every regression. 
The effect of globalization according to the level of income provides a different view. In middle-income countries, globalization is expected to widen the gap of education inequality and the result is similar for high-income countries. However, the results also reveal that there exists a different variation on the impact of globalization within the developing countries itself. This is the main contribution of the study, where we provide empirical evidence which shows that the $\mathrm{H}-\mathrm{O}$ theory assumption does not hold in developing countries and might explain why previous studies find conflicting or no significant evidence on the relationship between globalization and inequality ${ }^{9}$.

As predicted by the H-O theory, globalization should be beneficial for developing countries, which include both low and middle-income countries. When we distinguish the income level separately, it becomes obvious that globalization is beneficial to low-income countries only. For middle-income countries, globalization is associated with the increase in education inequality. It is also likely that, most of the middle-income countries (which are developing countries) in the sample are classified as 'upper middle income' which explains the variations in our findings.

Briefly, the control variables perform plausibly. The lagged dependent variables are positive and highly significant with coefficients range from 0.8- 0.9, signifying a high degree of persistence of the inequality measure. GDP per capita has a consistent negative effect on inequality which is expected as higher income would presumably lead to equal distribution. As hypothesized, age dependency is positively correlated with inequality although it is insignificant for the political regressions. Financial development is positive and significant, implying that the existence of a developed credit market to finance education is expected to widen the gap of educational attainment in the population. Even though financial development increases the access to capital for the poor and may reduce inequality, the benefit depends on the quality of institutions (World Economic Outlook, 2009). A positive effect of financial development may also be a sign for weak institutions which indicates that the benefits of financial development are unevenly distributed.

The diagnostic tests for system GMM confirm that the set of instruments is valid. This can be inferred from the non-rejection of the Hansen-J over identification test. We expect the presence of first order autocorrelation in the model, and we reject the null for the absence of second order autocorrelation. The test for first order serial correlation AR (1) shows that the null hypothesis is rejected in all estimations. The estimations have no second order serial correlations since the AR (2) test statistics fail to reject the null of second order serial correlation. Overall, the magnitudes of the estimated effects for the KOF indices and its dimensions on different levels of income are very close.

\subsection{Robustness Test ${ }^{10}$}

We now turn to examine the relationship between human capital inequality and alternative measures of globalization in Table 3 as robustness check. We present the results for the effect of frequently used globalization measures in existing studies with different levels of income. The effect of openness appears to be insignificant compared to the other two measures. Both FDI and freedom to trade have similar effects on human capital inequality with the KOF indices, but the coefficients for FDI are quite small. In addition, for the two globalization measures, the effect of globalization in middle and high-

\footnotetext{
${ }^{9}$ We find opposite effects of globalization compared to Bergh and Nilsson (2010) and Dreher and Gaston (2008). The former find that economic globalization has positive effect on the distribution of income in low and middle-income countries, while the latter find insignificant effect of aggregate globalization in non-OECD countries.

${ }^{10} \mathrm{We}$ also conduct other robustness and sensitivity analysis. Results are available upon request.
} 
income countries is positive. Other control variables behave expectedly although rarely significant. The lagged dependent variables are once again positive and significant in both cases with considerable persistency.

Table 3: Robustness Test: Alternative Measures of Globalization [System GMM]

\begin{tabular}{|c|c|c|c|c|c|c|}
\hline Variables & (1) Open & (2) FDI & (3) EF & (4) Open & (5) FDI & (6) EF \\
\hline Openness & $\begin{array}{c}-0.020 * * \\
(0.008)\end{array}$ & & & $\begin{array}{l}-0.102 \\
(1.243)\end{array}$ & & \\
\hline FDI & & $\begin{array}{c}-0.005 * * * \\
(0.001)\end{array}$ & & & $\begin{array}{l}-0.085 \\
(0.110)\end{array}$ & \\
\hline EF Index & & & $\begin{array}{c}-0.051 * * * \\
(0.014)\end{array}$ & & & $\begin{array}{c}-1.361 * * \\
(0.608)\end{array}$ \\
\hline Openness*Middle & & & & $\begin{array}{l}-0.256 \\
(1.322)\end{array}$ & & \\
\hline Openness*High & & & & $\begin{array}{c}0.125 \\
(1.244)\end{array}$ & & \\
\hline FDI*Middle & & & & & $\begin{array}{c}0.116 \\
(0.116)\end{array}$ & \\
\hline FDI*High & & & & & $\begin{array}{c}0.098 \\
(0.110)\end{array}$ & \\
\hline EF*Middle & & & & & & $\begin{array}{l}1.090^{*} \\
(0.645)\end{array}$ \\
\hline EF*High & & & & & & $\begin{array}{l}1.537 * * \\
(0.637)\end{array}$ \\
\hline $\operatorname{Gini} 25(\mathrm{t}-1)$ & $\begin{array}{c}0.899 * * * \\
(0.018)\end{array}$ & $\begin{array}{c}0.867 * * * \\
(0.021)\end{array}$ & $\begin{array}{c}0.831 * * * \\
(0.022)\end{array}$ & $\begin{array}{c}0.920 * * * \\
(0.014)\end{array}$ & $\begin{array}{c}0.887 * * * \\
(0.021)\end{array}$ & $\begin{array}{c}0.869 * * * \\
(0.019)\end{array}$ \\
\hline Middle & & & & $\begin{array}{c}3.116 \\
(5.661)\end{array}$ & $\begin{array}{c}1.882 \\
(1.557)\end{array}$ & $\begin{array}{l}-5.354 \\
(3.975)\end{array}$ \\
\hline High & & & & $\begin{array}{c}5.771 \\
(5.819)\end{array}$ & $\begin{array}{c}6.223 * * \\
(2.605)\end{array}$ & $\begin{array}{l}-5.703 \\
(4.382)\end{array}$ \\
\hline GDP & $\begin{array}{c}0.007 * * * \\
(0.003)\end{array}$ & $\begin{array}{c}-0.008 * * \\
(0.004)\end{array}$ & $\begin{array}{c}-0.007 * \\
(0.004)\end{array}$ & $\begin{array}{c}-2.740 * * * \\
(0.827)\end{array}$ & $\begin{array}{c}-3.176^{* * *} \\
(0.915)\end{array}$ & $\begin{array}{c}-2.137 * * \\
(0.905)\end{array}$ \\
\hline Finance & $\begin{array}{c}0.008 * * * \\
(0.003)\end{array}$ & $\begin{array}{c}0.007 * * \\
(0.003)\end{array}$ & $\begin{array}{c}0.009 * * * \\
(0.003)\end{array}$ & $\begin{array}{l}0.543^{*} \\
(0.304)\end{array}$ & $\begin{array}{l}0.509^{*} \\
(0.291)\end{array}$ & $\begin{array}{l}0.658^{*} \\
(0.336)\end{array}$ \\
\hline Age & $\begin{array}{c}0.018 \\
(0.012)\end{array}$ & $\begin{array}{l}0.025^{*} \\
(0.013)\end{array}$ & $\begin{array}{c}0.026 * * \\
(0.012)\end{array}$ & $\begin{array}{c}-0.324 * \\
(0.190)\end{array}$ & $\begin{array}{l}-0.219 \\
(0.186)\end{array}$ & $\begin{array}{l}-0.031 \\
(0.155)\end{array}$ \\
\hline Constant & $\begin{array}{c}0.094 \\
(0.070)\end{array}$ & $\begin{array}{c}0.005 \\
(0.062)\end{array}$ & $\begin{array}{c}0.092 \\
(0.070)\end{array}$ & $\begin{array}{c}22.767 * * * \\
(7.826)\end{array}$ & $\begin{array}{c}27.504 * * * \\
(7.175)\end{array}$ & $\begin{array}{c}28.289 * * * \\
(8.365)\end{array}$ \\
\hline Observations & 688 & 649 & 590 & 653 & 646 & 559 \\
\hline AR1 $p$-value & 0.01 & 0.02 & 0.03 & 105 & 105 & 95 \\
\hline AR2 $p$-value & 0.08 & 0.23 & 0.21 & 0.01 & 0.02 & 0.02 \\
\hline Hansen $\mathbf{J} p$-value & 0.10 & 0.17 & 0.13 & 0.08 & 0.10 & 0.13 \\
\hline
\end{tabular}

Notes: Robust standard errors in parentheses. $* * * \mathrm{p}<0.01, * * \mathrm{p}<0.05, * \mathrm{p}<0.1$. The dependent variable is human capital gini for population aged 25 years and above. Significant time dummies are included in every regression.

Overall, the magnitudes of the estimated effects for the KOF indices and the EF index on different levels of income are very close. For example, one-point increase in the composite KOF index (EF index) in middle-income countries is associated with an increase of 0.06 per cent $(0.05$ per cent) of human capital inequality. The traditional measure of globalization, openness, does not seem to affect inequality, which 
confirms the finding from Dollar and Kraay (2002), Edwards (1997), and Higgins and Williamsons (1999). This also suggests that conceptually, the basic H-O theory does not hold for openness. As for the FDI, we find contrasting results with Basu and Guariglia (2007). This is also in contrast with Sylwester (2005), in which he finds no association between FDI and the distribution of income in a sample of Less Developed Countries (LDCs).

In general, the preliminary evidence suggests that different dimensions of globalization are also important for inequality and the significance of the effect of globalization on inequality depend on the measure of globalization used (generally negative and significant and support the H-O theory partially for globalization index, generally insignificant for openness/GDP and FDI).

\section{CONCLUSION}

We find two different patterns within the developing countries, which disapprove the standard $\mathrm{H}-\mathrm{O}$ theory. The results imply that low-income countries benefit from globalization; while in contrast, globalization widens the educational gap in middle-income countries. The findings suggest that, the benefits gained from globalization by developing countries as theorized by the basic $\mathrm{H}-\mathrm{O}$ theory is actually distributed only to the countries with very low GDP per capita. For developed or high-income countries, education inequality increases with globalization, which follows the assumptions of the $\mathrm{H}-\mathrm{O}$ theory.

These results might be an important lead for policy considerations. We prove that unraveling the different dimensions of globalization is important and globalization affects the distribution of education differently according to the level of development. On the other hand, the effect of globalization is less robust and insignificant when globalization is measured by openness, FDI or EF index. In fact, openness does not seem to be significant in all specifications. It is also safe to conclude that the effect of globalization on inequality depends on the proxy or measures used. We show that an aggregate indicator of globalization provides better and more robust result compared to the traditional measures of globalization. We also prove social and political globalization as important determinants of human capital inequality.

We believe that the results motivate a new finding; the effects of globalization on inequality vary even in the developing countries, with beneficial effects only in low income countries. Our study reveals some interesting results, which open the door for further research both theoretically and empirically. Further research is needed based on the novelty findings and scarcity of theoretical models on globalization and human capital inequality. For the theoretical study, we suggest in depth analysis to investigate further the validity and reliability of the standard $\mathrm{H}-\mathrm{O}$ theory especially for the developing countries, by differentiating the low and middle-income countries. Empirically, more study should focus on globalization and human capital inequality and studying the impact of globalization on the educational quintiles may provide an additional support on this novel finding.

\section{ACKNOWLEDGMENT}

This research was supported by Ministry of Education Malaysia (Fundamental Research Grant: 5524722) 


\section{REFERENCES}

Alesina, A., \& Rodrik, D. (1994). Distributive Politics and Economic Growth. The Quarterly Journal of Economics, 109(2), 465-490.

Anderson, E. (2005). Openness and Inequality in Developing Countries: A Review of Theory and Recent Evidence. World Development, 33(7), 1045-1063.

Arellano, M., \& Bover, O. (1995). Another Look at the Instrumental Variable Estimation of ErrorComponents Models. Journal of Econometrics, 68(1), 29-51.

Arellano. M., \& Bond, S. R. (1991). Some Tests of Specification for Panel Data: Monte Carlo Evidence and an Application to Employment Equations. Review of Economics Studies, 58(2), 277-297.

Banerjee, A., \& Newman, A. (1993). Occupational Choice and the Process of Development. Journal of Political Economy 101(2), 274-298.

Barro, R. J., \& Lee, J. W. (2010). A New Data Set of Educational Attainment in the World, 1950-2010. NBER Working Paper No. 15902.

Basu, P., \& Guariglia, A. (2007). Foreign Direct Investment, Inequality and Growth. Journal of Macroeconomics, 29(4), 824-839.

Bechtel, G. (2014). Does Globalization Mitigate Income Inequality? Journal of Data Science, 12(2014), 197-215.

Beck, T., Demirgüç-Kunt, A., \& Levine, R. (2009). Financial Institutions and Markets Across Countries and Over Time: Data and Analysis. World Bank Policy Research Working Paper 4943.

Bergh, A., \& Nilsson, T. (2010). Do Liberalization and Globalization Increase Income Inequality? European Journal of Political Economy, 26(4),488-505.

Blundell, R., \& Bond, S. (2000). GMM Estimation with Persistent Panel Data: An Application to Production Functions. Econometric Reviews, 19(3), 321-340.

Burtless, G. (2002). Can Supply-Side Policies Reduce Unemployment? Lessons from North America. Australian Journal of Labor Economics (AJLE), The Centre for Labor Market Research (CLMR), Curtin Business School, 5(2), 115-142.

Calderon, C., \& Chong, A. (2001). External Sector and Income Inequality in Interdependent Economies Using a Dynamic Panel Data Approach. Economics Letters, 71(2), 225-231.

Castelló, A., \& Doménech, R. (2002). Human Capital Inequality and Economic Growth: Some New Evidence. Economic Journal, 112(478), 187-200.

Checchi, D. (2001). Education, Inequality and Income Inequality. STICERD -Distribution Analysis Research Program Papers 52.

Checchi, D., \& Garcia-Penalossa, C. (2004). Risk and the Distribution of Human Capital. Economics Letters, 82(1), 53-61.

Deininger, K., \& Squire, L. (1998). A New Data Set Measuring Income Inequality. World Bank Economic Review, 10(3), 565-591.

Dollar, D., \& Kraay, A. (2002). Growth is Good for the Poor. Journal of Economic Growth, 7(3), 195 225.

Dreher, A. (2006). Does Globalization Affect Growth? Evidence from a New Index of Globalization. Applied Economics, 38(10), 1091-1110.

Dreher, A., \& Gaston, N. (2008). Has Globalization Increased Inequality? Review of International Economics, 16(3), 516-536.

Dreher, A., Gaston, N., \& Martens, P. (2008). Measuring Globalization - Gauging Its Consequence. New York: Springer.

Edwards, S. (1997). Trade Policy, Growth and Income Distribution. American Economic Review, 87(2), 205-210. 
Galor, O., \& Tsiddon, D. (1997). The Distribution of Human Capital and Economic Growth. Journal of Economic Growth, 2(1), 93-124.

Galor, O., \& Zeira, J. (1993). Income Distribution and Macroeconomics. Review of Economic Studies, 60(1), 35-52.

Gaston, N., \& Rajaguru, G. (2009). Has globalization increased Australian inequality? In J. Corbett, A. Daly, H. Matsushige \& D. Taylor (Eds.), Laggards and Leaders in Labour Market Reform: Comparing Japan And Australia (pp. 85-108). USA: Routledge.

Glomm, G., \& Ravikumar, B. (1992). Public versus Private Investment in Human Capital: Endogenous Growth and Income Inequality. The Journal of Political Economy, 100(4), 818-834.

Gwartney, J., \& Lawson, R. (2003). Economic Freedom of the World Annual Report. Vancouver BC: The Fraser Institute.

Higgins, M., \& Williamson, J. G. (1999). Explaining Inequality the World Round: Cohort Size, Kuznets Curves and Openness. National Bureau of Economic Research Working Paper 7224.

Holtz-eakin, D., Newey, W., \& Rosen, H. S. (1988). Estimating Vector Autoregressions with Panel Data. Econometrica, 56(6), 1371-1395.

Kanbur, R. (2000). Income Distribution and Development. In A. B. Atkinson \& F Bourguignon (Eds.), Handbook of Income Distribution (pp. 791-841). Amsterdam: Elsevier North-Holland.

Kremer, M., \& Maskin, E. (2003). Globalization and Inequality. Unpublished manuscript, Harvard University.

Lundberg, M., \& Squire, S. (2003). The Simultaneous Evolution of Growth and Inequality. Economic Journal, 113(487), 326-344.

Milanovic, B. (2005). Can We Discern the Effect of Globalization on Income Distribution? Evidence from Household Budget Surveys. The World Bank Economic Review, 19(1), 21-44

Piketty, T. (1997). The Dynamics of The Wealth Distribution and The Interest Rate With Credit Rationing. Review of Economic Studies, 64(2), 173-189.

Ravallion, M. (2001). Growth, Inequality and Poverty: Looking Beyond Averages. World Development, 29(11),1803-1815.

Roodman, D. (2009a). How to Do xtabond2: An Introduction to Difference and System GMM in Stata. Stata Journal, StataCorp LP, 9(1), 86-136.

Roodman, D. (2009b). A Note on the Theme of Too Many Instruments. Oxford Bulletin of Economics and Statistics, 71(1),135-158.

Sachs, J. D., \& Warner, A. (1995). Economic Reform and The Process of Global Integration. Brookings Papers on Economic Activity, 26(1), 1-118.

Saint-Paul, G., \& Verdier, T. (1993). Education, Democracy and Growth. Journal of Development Economics, 42(2), 399-407.

Savvides, A. (1998). Trade Policy and Income Inequality: New Evidence. Economics Letters, 61(3), 365-372.

Sylwester, K. (2005). Foreign Direct Investment, Growth and Income Equality in Less Developed Countries. International Review of Applied Economics, 19(3), 289-300.

Tayebi, S. K., \& Ohadi, S.E. (2009). Globalization and Inequality in Different Economic Blocks. Iranian Economic Review, 14(24), 136-151.

Thomas, V., Wang, Y., \& Fan, X. (2001). Measuring Education Inequality: Gini Coefficients of Education for 140 Countries, 1960-2000. Journal of Education Planning and Administration, 17(1), 5-33.

Windmeijer, F. (2005). A finite sample correction for the variance of linear efficient two step GMM estimators. Journal of Econometrics, 126(1), 25-51.

World Economic Outlook (2009). World Economic and Financial Survey: Crisis and Recovery. Washington, D.C.: International Monetary Fund. 


\section{APPENDICES}

Table A.1: The KOF Index of Globalization

\begin{tabular}{|lc|}
\hline Indices and Variables & Weights \\
\hline A. Economic Globalization & {$[\mathbf{3 6 \%}$} \\
i) Actual Flows & $(50 \%)$ \\
Trade (per cent of GDP) & $(22 \%)$ \\
Foreign Direct Investment, stocks (per cent of GDP) & $(29 \%)$ \\
Portfolio Investment (per cent of GDP) & $(22 \%)$ \\
Income Payments to Foreign Nationals (per cent of GDP) & $(27 \%)$ \\
ii) Restrictions & $(50 \%)$ \\
Hidden Import Barriers & $(22 \%)$ \\
Mean Tariff Rate & $(28 \%)$ \\
Taxes on International Trade (per cent of current revenue) & $(27 \%)$ \\
Capital Account Restrictions & $(23 \%)$ \\
B. Social Globalization & {$[\mathbf{3 8 \%}$} \\
i) Data on Personal Contact & $(33 \%)$ \\
Telephone Traffic & $(26 \%)$ \\
Transfers (per cent of GDP) & $(2 \%)$ \\
International Tourism & $(26 \%)$ \\
Foreign Population (per cent of total population) & $(20 \%)$ \\
International letters (per capita) & $(25 \%)$ \\
ii) Data on Information Flows & $(36 \%)$ \\
Internet Users (per 1000 people) & $(36 \%)$ \\
Television (per 1000 people) & $(37 \%)$ \\
Trade in Newspapers (per cent of GDP) & $(28 \%)$ \\
iii) Data on Cultural Proximity & $(31 \%)$ \\
Number of McDonald's Restaurants (per capita) & $(43 \%)$ \\
Number of Ikea (per capita) & $(44 \%)$ \\
Trade in books (per cent of GDP) & $(13 \%)$ \\
C. Political Globalization & {$[\mathbf{2 6 \%}$} \\
Embassies in Country & $(25 \%)$ \\
Membership in International Organizations & $(28 \%)$ \\
Participation in U.N. Security Council Missions & $(22 \%)$ \\
International Treaties & $(25 \%)$ \\
\hline
\end{tabular}

Source: Dreher (2006) Does Globalization Affect Growth? Empirical Evidence from a new Index, Applied Economics 38, 10: 1091-1110. Updated in: Gaston and Martens (2008) Measuring Globalization-Gauging its Consequence, New York: Springer.

\section{Economic Globalization (KOF1)}

Flows of goods, services, capital and information from abroad are considered as economic globalization. Economic globalization is constructed from two components: actual flows and restrictions. Foreign direct investment is the biggest subcomponent for actual flows, followed by income payments to foreign nationals. Both trade and portfolio investments are equally weighted in this index component (22\%). Foreign direct investment includes both outflow and inflow, which are common measures of globalization. Income payments to foreign nationals are included to proxy for the numbers of foreign labor and capital during the production process. The second component is on restrictions, which include tariff, taxes, import barriers and capital account restrictions. In general, this economic index combines the suggested measure of globalization in previous literature to construct a better and extensive index to proxy globalization. 


\section{Social Globalization (KOF2)}

Social globalization captures factors on personal contact, information flows and cultural proximity. Personal contact measures the communication between people in different countries. This measure is a combined measure of telephone traffics, international tourism, government transfers and foreign population. The stock of foreign population evaluates the existing interactions of people with people outside the country, while international calls are the estimates of the cost of interactions. Information flow includes the importance of mass media (internet, television and newspaper) as mediums for information exchanges. Cultural proximity is measured by using the number of McDonald's restaurants, number of IKEA stores and trade of books. Theoretically, no predictions have been made on the effect of social globalization on inequality. Furthermore, Dreher and Gaston (2008) classified the cultural proximity as "the most difficult dimension to grasp."

\section{$\underline{\text { Political Globalization (KOF3) }}$}

Political globalization is the dimension with the lowest weight (26\%). This dimension measures the number of embassies, membership in international organizations and participation in the UN Security Council Missions and international treaties.

Table A.2: Correlation Matrix

\begin{tabular}{cccccccccccc}
\hline \hline & Gini & KOF & KOF1 & KOF2 & KOF3 & FDI & Open & EF & GDP & Age & Finance \\
\hline Gini & 1 & & & & & & & & & & \\
KOF & -0.680 & 1 & & & & & & & & & \\
KOF1 & -0.642 & 0.913 & 1 & & & & & & & & \\
KOF2 & -0.684 & 0.952 & 0.853 & 1 & & & & & & & \\
KOF3 & -0.366 & 0.672 & 0.395 & 0.507 & 1 & & & & & & \\
FDI & -0.096 & 0.174 & 0.235 & 0.169 & -0.001 & 1 & & & & \\
Open & -0.144 & 0.287 & 0.476 & 0.323 & -0.208 & 0.360 & 1 & & & \\
EF & -0.448 & 0.709 & 0.756 & 0.628 & 0.395 & 0.169 & 0.333 & 1 & & \\
GDP & -0.568 & 0.796 & 0.709 & 0.840 & 0.426 & 0.363 & 0.235 & 0.517 & 1 & & \\
Age & 0.682 & -0.754 & -0.674 & -0.757 & -0.463 & -0.120 & -0.233 & -0.513 & -0.682 & 1 & \\
Finance & -0.414 & 0.666 & 0.623 & 0.681 & 0.348 & 0.202 & 0.273 & 0.465 & 0.687 & -0.588 & 1 \\
\hline \hline
\end{tabular}

